\title{
Experimental and computational study of the energetics of hydantoin and 2-thiohydantoin
}

\author{
Ana L.R. Silva, Álvaro Cimas, Nuno Vale, Paula Gomes, Manuel J.S. Monte, Maria D.M.C. Ribeiro da Silva*

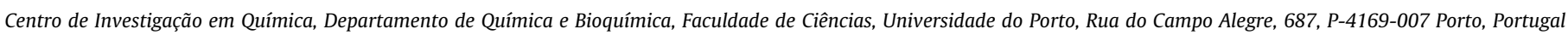

\section{A R T I C L E I N F O}

\section{Article history:}

Received 19 September 2012

Accepted 3 October 2012

Available online 8 November 2012

\section{Keywords:}

Imidazolidine

Hydantoin

2-Thiohydantoin

Enthalpy of formation

Enthalpy of sublimation

Combustion calorimetry

Vapour pressure

Knudsen effusion technique

Calvet microcalorimetry

Heat capacity

G3(MP2)//B3LYP composite method

\begin{abstract}
A B S T R A C T
This work reports an experimental and a theoretical study of two imidazolidine derivatives, hydantoin (CAS No. 461-72-3) and 2-thiohydantoin (CAS No. 503-87-7).

The standard $\left(p^{\circ}=0.1 \mathrm{MPa}\right)$ molar energies of combustion of hydantoin and 2-thiohydantoin were measured by static and rotating bomb combustion calorimetry, respectively. The standard molar enthalpies of sublimation, at $T=298.15 \mathrm{~K}$, were derived from the temperature dependence of the vapour pressures of these compounds, measured by the Knudsen-effusion technique, and from high temperature Calvet microcalorimetry. The conjugation of these experimental results enables the calculation of the standard molar enthalpies of formation in the gaseous state, at $T=298.15 \mathrm{~K}$, which are discussed in terms of structural contributions.

We have also estimated the gas-phase enthalpy of formation from high-level $a b$ initio molecular orbital calculations at the G3MP2B3 level of theory, being the computed values in good agreement with the experimental ones. Furthermore, this composite approach was also used to obtain information about the gas-phase basicities, proton and electron affinities and adiabatic ionization enthalpies.
\end{abstract}

(c) 2012 Elsevier Ltd. All rights reserved.

\section{Introduction}

The hydantoin nucleus corresponds to a five membered heterocycle, containing a reactive cyclic urea core. This imidazolidine structure is present in a wide range of biologically active compounds with important applications in medicinal fields, such as antitumor [1] and anti-arrhythmic agents [2], anti-cancer drugs [3] having also agrochemical applications (bactericides and fungicides) [4]. Therefore, the knowledge of the physico-chemical properties of this type of compounds is important, particularly those properties that are related with their reactivity.

The thermochemical data available for imidazolidine derivatives do not allow a sustained interpretation about the behaviour of such species. Experimental and computational studies for compounds with pentagonal ring cores, with two nitrogen atoms or a nitrogen and an oxygen or sulfur as heteroatoms, in the positions 1,3-, has been studied recently [5-8]. Other studies on the energetic of five-membered nitrogen heterocycles fused to a benzenic ring [9-11] have been also described in the recent literature. For hydantoin, there are studies [12] reporting the determination of the corresponding enthalpies of combustion and formation in the

\footnotetext{
* Corresponding author. Tel.: +351 220402 538; fax: +351 220402522 .

E-mail address: mdsilva@fc.up.pt (M.D.M.C. Ribeiro da Silva).
}

crystalline phase, although the results do not match with those obtained for related compounds and those presented in this work.

We are involved in an extensive study on the energetics of compounds having a five-membered ring with one nitrogen heteroatom and a second heteroatom (nitrogen, oxygen or sulfur) on a meta-position relatively to the first nitrogen. The present work reports thermodynamic experimental results on hydantoin and 2thiohydantoin (structural formula represented in figure 1), in order to contribute for their thermodynamic characterization. The standard $\left(p^{\circ}=0.1 \mathrm{MPa}\right.$ ) molar enthalpies of formation, in crystalline phase, $\Delta_{\mathrm{f}} H_{\mathrm{m}}^{\circ}(\mathrm{cr})$, at $T=298.15 \mathrm{~K}$, of both compounds were derived from their standard molar energies of combustion, in oxygen, at the temperature of $298.15 \mathrm{~K}$, measured by static or rotating bomb combustion calorimetry. The standard molar enthalpies of sublimation of those compounds, $\Delta_{\mathrm{cr}}^{\mathrm{g}} H_{\mathrm{m}}^{\circ}$, at $T=298.15 \mathrm{~K}$, were derived indirectly from the temperature dependence of the vapour pressures of these compounds, measured by the Knudsen-effusion technique, and directly using high temperature Calvet microcalorimetry. From the experimental results, the standard molar enthalpies of formation in the gaseous state, at $T=298.15 \mathrm{~K}$, were derived and are discussed in terms of structural contributions, in order to evaluate the energetic effects associated to the replacement of a $\mathrm{C}=\mathrm{O}$ group by a $\mathrm{C}=\mathrm{S}$ group in the ring.

Additionally, through high level $a b$ initio calculations, the gasphase standard molar enthalpies of formation of these compounds 


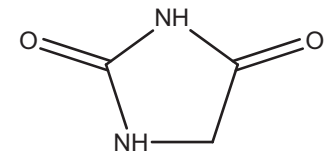

(1)

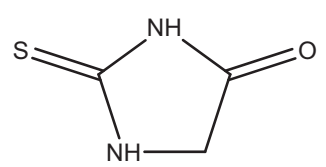

(2)
FIGURE 1. Structural formula of the two imidazolidine derivatives studied: (1) hydantoin, (2) 2-thiohydantoin.

as well as the gas-phase basicities, proton and electron affinities and adiabatic ionization enthalpies, were estimated.

\section{Experimental}

\subsection{Materials}

Hydantoin (CAS No. 461-72-3) and 2-thiohydantoin (CAS No. 503-87-7) were supplied by Alfa Aesar with lot certificated purity of 0.994 and 0.997 mass fraction, respectively. Both compounds were purified by repeated sublimation under reduced pressure. The purity of the samples was confirmed by gas chromatography, yielding molar fractions higher than 0.999. The initial and final purities of the samples are presented in table 1.

The structures of both purified samples were confirmed by electrospray ionization-ion trap mass spectrometry (ESI-IT MS) and by proton $\left({ }^{1} \mathrm{H}-\right)$ and carbon $\left({ }^{13} \mathrm{C}-\right)$ nuclear magnetic resonance (NMR). All spectroscopic data and spectral traces are supplied in the Supplementary Material.

For the calibration of the static and rotating bombs, benzoic acid NBS SRM 39j was used, while anthracene (Aldrich Chemical Co., zone-refined 99+\%) was used to calibrate the Calvet microcalorimeter. Three high-purity reference materials [13]: benzoic acid (NIST Standard Reference Material 39i), tin and indium (Aldrich, mass fraction $>0.99999$ ) were used to calibrate the temperature scale of the differential scanning calorimeter (DSC), whereas the power scale was calibrated with a highly pure indium sample.

The specific densities of the compounds studied were taken from literature, as $\rho=1.3105 \mathrm{~g} \cdot \mathrm{cm}^{-3}$ for hydantoin [14] and $\rho=1.3456 \mathrm{~g} \cdot \mathrm{cm}^{-3}$ for 2-thiohydantoin [14], and the relative atomic masses used for the elements were the ones recommended by the IUPAC commission in 2009 [15].

\subsection{Enthalpies and temperatures of fusion}

The temperatures and the enthalpies of fusion of the two compounds were determined using a differential scanning calorimetry (DSC, Setaram DSC 141). The samples were sealed in aluminium crucibles and five runs were done for each compound, under nitrogen atmosphere, using a heating rate of $3.3 \times 10^{-2} \mathrm{~K} \cdot \mathrm{s}^{-1}$. The temperature and power scales of the calorimeter were calibrated under the same conditions as the experimental determinations.

The temperature and the enthalpy of fusion obtained for hydantoin were $T_{\text {fus }}=(495.8 \pm 0.2) \mathrm{K}$ and $\Delta_{\mathrm{cr}}^{1} H_{\mathrm{m}}^{\circ}\left(T_{\text {fus }}\right)=(24.8 \pm 0.3) \mathrm{kJ} \cdot \mathrm{mol}^{-1}$. For 2-thiohydantoin, the results $T_{\text {fus }}=(506.1 \pm 0.5) \mathrm{K}$ and $\Delta_{\mathrm{cr}}^{1} H_{\mathrm{m}}^{\circ}\left(T_{\text {fus }}\right)$ $=(27.1 \pm 0.6) \mathrm{kJ} \cdot \mathrm{mol}^{-1}$ were obtained. No phase transitions were detected in the crystalline phase, between $T=298 \mathrm{~K}$ and the temperature of fusion of each compound.

\subsection{Combustion calorimetry}

The standard $\left(p^{\circ}=0.1 \mathrm{MPa}\right)$ massic energy of combustion of hydantoin and 2-thiohydantoin were determined using two different isoperibol bomb combustion calorimeters:

(i) Static-bomb calorimeter with a twin valve bomb and an internal volume of $0.290 \mathrm{dm}^{3}$, with a detailed description in the literature [16]. The calorimeter temperatures were measured to $\pm\left(1 \times 10^{-4}\right) \mathrm{K}$, at time intervals of $10 \mathrm{~s}$, with a S10 four wire calibrated ultra-stable thermistor probe (Thermometrics, standard serial No. 1030) and recorded by a high sensitivity nanovolt/microohm meter (Hewlett-Packard, HP 34420 A) interfaced to a PC. The initial temperature was close to $T=298.15 \mathrm{~K}$.

(ii) Rotating-bomb calorimeter with a stainless steel twin valve bomb, lined with platinum, whose internal volume is 0.258 $\mathrm{dm}^{3}$, previously described in the literature [17]. The calorimeter temperatures were measured to $\pm\left(1 \times 10^{-4}\right) \mathrm{K}$, at time intervals of $10 \mathrm{~s}$, using a Hewlett-Packard (HP-2804 A) quartz thermometer, interfaced to a PC. The final temperature was close to $T=298.15 \mathrm{~K}$ and the bomb rotation was started when the temperature rise in the main-period reached about 0.63 of its total value, and continued until the end of each experiment.

The two calorimetric systems were calibrated using benzoic acid having a massic energy of combustion, under standard bomb conditions, of $-(26434 \pm 3) \mathrm{J} \cdot \mathrm{g}^{-1}$. The calibration results were corrected to give an energy equivalent, $\varepsilon_{\mathrm{cal}}$, corresponding to an average mass of water added to the static-bomb or rotating-bomb calorimeters of $2900.0 \mathrm{~g}$ or $5222.5 \mathrm{~g}$, respectively. For the static calorimeter system, six calibration experiments were made in an oxygen atmosphere at $p=3.04 \mathrm{MPa}$, with $1.00 \mathrm{~cm}^{3}$ of deionised water added to the bomb, leading to an energy equivalent of the calorimeter of $\varepsilon_{\text {cal }}=(15551.7 \pm 1.2) \mathrm{J} \cdot \mathrm{K}^{-1}$. For the rotating calorimeter system, six calibration experiments were made in the conditions above referred and without rotation, yielding an energy equivalent of the calorimeter of $\varepsilon_{\text {cal }}=(25157.4 \pm 1.1) \mathrm{J} \cdot \mathrm{K}^{-1}$. The uncertainties mentioned are the standard deviations of the means.

The samples of the two compounds, in pellet form, were ignited in an oxygen atmosphere $(p=3.04 \mathrm{MPa})$, with $1.00 \mathrm{~cm}^{3}$ and $20.00 \mathrm{~cm}^{3}$ of deionised water added to the bomb, for hydantoin and 2-thiohydantoin, respectively. $n$-Hexadecane (Aldrich, Gold Label), with a massic energy of combustion of $\Delta_{\mathrm{c}} u^{\circ}=-(47126.0$ $\pm 4.1) \mathrm{J} \cdot \mathrm{g}^{-1}$, was used as auxiliary of combustion to produce an appropriate temperature rise. For the cotton thread fuse (empirical formula $\left.\mathrm{CH}_{1.686} \mathrm{O}_{0.843}\right), \Delta_{\mathrm{c}} u^{\circ}=-16240 \mathrm{~J} \cdot \mathrm{g}^{-1}$ [18]; both values have been previously confirmed in our laboratory. The electric energy for ignition was determined from the change in potential difference on discharge of a $1400 \mu \mathrm{F}$ condenser across a platinum wire. A value for the pressure coefficient of specific energy $(\partial u / \partial p)_{\mathrm{T}}=$ $-0.2 \mathrm{~J} \cdot \mathrm{g}^{-1} \mathrm{MPa}^{-1}$ at $T=298.15 \mathrm{~K}$, a typical value for organic compounds was assumed [19]. For the static-bomb, the amount of

TABLE 1

Source, purification, and analysis details of the studied samples.

\begin{tabular}{|c|c|c|c|c|c|}
\hline Chemical name & Source & Lot certificate purity & Purification method & Final molar purity & Analysis method \\
\hline Hydantoin & Alfa-Aesar & 0.994 & Sublimation & 0.9993 & $\mathrm{GC}^{a}$ \\
\hline 2-Thiohydantoin & Alfa-Aesar & 0.997 & Sublimation & 0.9995 & $\mathrm{GC}^{a}$ \\
\hline
\end{tabular}

\footnotetext{
${ }^{a}$ GC - gas-liquid chromatography.
} 
the compound burnt in each experiment was determined from the total mass of carbon dioxide produced, taking into account that originated by the combustion of the cotton thread fuse and from the $n$-hexadecane.

For the rotating-bomb, the nitric acid formed was determined using Devarda's alloy method [20] and the correction energy for the formation of $0.1 \mathrm{~mol} \cdot \mathrm{dm}^{-3} \mathrm{HNO}_{3}$ (aq) solution from $\mathrm{N}_{2}(\mathrm{~g})$, $\mathrm{O}_{2}(\mathrm{~g})$ and $\mathrm{H}_{2} \mathrm{O}(\mathrm{l})$ was calculated considering the value $-59.7 \mathrm{~kJ} \cdot \mathrm{mol}^{-1}[21]$.

The standard massic energy of combustion, $\Delta_{\mathrm{c}} u^{\circ}$, was calculated by a similar procedure to that developed by Hubbard et al. [22] for compounds with general formula $\mathrm{C}_{a} \mathrm{H}_{b} \mathrm{O}_{c} \mathrm{~N}_{d}$, and by Good et al. [23] for sulfur compounds.

\subsection{Vapour pressures measurements}

The Knudsen effusion technique was used to measure the vapour pressure of crystalline samples of the compounds, as function of temperature, being the standard molar enthalpies of sublimation, at $T=298.15 \mathrm{~K}$, derived by the Clausius-Clapeyron equation, using estimated values of the heat capacity differences, $\Delta_{\mathrm{cr}}^{\mathrm{g}} C_{p, \mathrm{~m}}^{\circ}$.

The Knudsen effusion apparatus has been designed and constructed in our research group and the detailed description of the procedure and technique used were published before [24]. The sublimation chamber contains three aluminium blocks, each one with three effusion cells. The apparatus is prepared for the simultaneous use of nine effusion cells grouped in three series ("Small" series A; "Medium" - series B; "Large" - series C, not used in the present work). The areas and Clausing factors of the effusion orifices are presented in table S1 of Supplementary information. During an effusion experiment, each aluminium block is kept at a constant temperature, different from the other two blocks. The temperature of each block is measured by a platinum resistance thermometer Pt-100 class 1/10. The pumping system combines a rotary pump (Edwards model RV12) with an oil diffusion pump (Edwards cryo-cooled diffstack model CR160) enabling the evacuation of the system to a pressure about $\left(5 \times 10^{-5}\right) \mathrm{Pa}$.

For the temperature $T$, the vapour pressure $p$ of the crystalline compound is related to the mass $m$ of the sample sublimed from each effusion cell, during the time period $t$ by equation (1), where $M$ is the molar mass of the effusion vapour, $R$ is the molar gas constant, $A_{0}$ is the area of the effusion orifice and $w_{0}$ is the respective Clausing factor.

$p=\left(m / A_{0} w_{0} t\right) \cdot(2 \pi R T / M)^{1 / 2}$.

\subsection{High-temperature microcalorimetry}

The enthalpies of sublimation of the two compounds were measured with a high-temperature Calvet microcalorimeter (Setaram HT 1000), using the "vacuum sublimation" drop microcalorimetric method described by Skinner [25]. The details of the apparatus and the technique used were previously described in detail [26].

Samples, about ( 3 to 5 ) $\mathrm{mg}$ of the compounds, contained in thin glass capillary tubes, were simultaneously dropped at a known room temperature into each of the calorimetric cells (reference and reaction) held at $T=447 \mathrm{~K}$ for hydantoin and $T=463 \mathrm{~K}$ for 2 thiohydantoin, and then removed from the hot zone by vacuum sublimation.

The calibration constants of the calorimeter, $k$, were obtained as the average of six independent experiments with anthracene, $k=(1.0021 \pm 0.0124)$ and $k=(1.0015 \pm 0.0074)$, respectively, for the referred pre-defined temperatures.

\section{Computational details}

Standard $a b$ initio molecular orbital calculations were performed with the Gaussian 03 series of programs [27]. The G3MP2B3 level of theory was employed throughout this work [28]. This is a variation of the G3MP2 theory [29] which uses the B3LYP density functional method [30,31] for geometries and zero-point energies. The B3LYP functional uses a combination of the hybrid three-parameter Becke's functional, first proposed by Becke [30], together with the Lee-Yang-Parr non-local correlation functional [32].

The computations carried out at the G3MP2B3 level use the B3LYP method and the 6-31G(d) basis set for both the optimization of geometry and calculation of frequencies. Introduction of highorder corrections to the B3LYP/6-31G(d) enthalpy is done in a manner that follows the Gaussian-3 philosophy, albeit using a second-order Moller-Plesset perturbation instead of MP4 as in the original G3 method [33].

The enthalpy of formation of these compounds was estimated after the consideration of the following gas-phase working reactions:

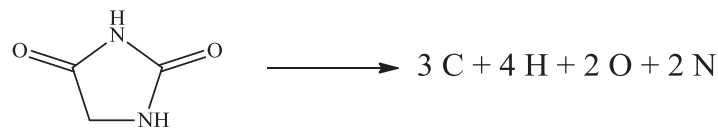

Hydantoin<smiles>O=C1CCCC1</smiles><smiles>O=C1CNC(=O)N1</smiles><smiles>c1ccccc1</smiles><smiles>CSc1nc2ccccc2[nH]1</smiles><smiles>O=CC[NH+]1C[CH-]CC1</smiles>

Ethanal 


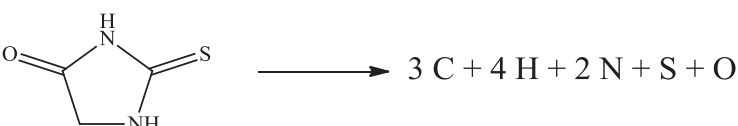

2-Thiohydantoin<smiles>C=C1NCC(=O)N1</smiles>

2-Thiohydantoin<smiles>O=C1CNC(=S)N1</smiles>

2-Thiohydantoin<smiles>C1CCOC1</smiles><smiles>[CH-]1CC1</smiles><smiles>S=C1CCCO1</smiles>
1,3-Oxazolidin-2-thione same computational approach was used to calculate also the ionization enthalpies, proton and electron affinities and gas-phase basicities. For that purpose, the G3MP2B3 computations were also extended to cationic, anionic and radical species of these compounds.
These reactions have been chosen on the basis of the availability of reliable experimental thermochemical data for the compounds there used.

The energies computed at $T=0 \mathrm{~K}$ were thermally corrected for $T=298.15 \mathrm{~K}$ by introducing the vibrational, translational, rotational and the $p V$ terms. The vibrational term is based on the vibrational frequencies calculated at the B3LYP/6-31G(d) level. The

TABLE 2

Typical combustion results for the compounds studied, at $T=298.15 \mathrm{~K}$.

\begin{tabular}{lll}
\hline & Hydantoin & 2-Thiohydantoin \\
\hline$m$ (cpd)/g & 0.77735 & 0.79647 \\
$m$ (fuse)/g & 0.00303 & 0.00278 \\
$m(n$-hexadec. $) / g$ & 0.10447 & 0.10396 \\
$T_{\mathrm{i}} / \mathrm{K}$ & 298.1514 & 297.3737 \\
$T_{\mathrm{f}} / \mathrm{K}$ & 299.2078 & 298.1727 \\
$\Delta T_{\mathrm{ad}} / \mathrm{K}$ & 0.97606 & 0.7836 \\
$\varepsilon_{\mathrm{i}} / \mathrm{J} \cdot \mathrm{K}^{-1}$ & 14.17 & 93.06 \\
$\varepsilon_{\mathrm{f}} / \mathrm{J} \cdot \mathrm{K}^{-1}$ & 14.65 & 92.26 \\
$\varepsilon_{\text {cal }} / \mathrm{J} \cdot \mathrm{K}^{-1}$ & 15547.5 & 25155.31 \\
$\Delta m\left(\mathrm{H}_{2} \mathrm{O}\right) / \mathrm{g}$ & -1.0 & -0.5 \\
$-\Delta U(\mathrm{IPB}) / \mathrm{J}$ & 15189.61 & 19784.36 \\
$\Delta U($ fuse $) / \mathrm{J}$ & 49.21 & 45.15 \\
$\Delta U(n-\mathrm{hexadec}.) / \mathrm{J}$ & 4923.22 & 4899.16 \\
$\Delta U\left(\mathrm{HNO} \mathrm{H}_{3}\right) / \mathrm{J}$ & 59.44 & 75.16 \\
$\Delta U($ ign $) / \mathrm{J}$ & 0.98 & 1.02 \\
$\Delta U_{\Sigma} / \mathrm{J}$ & 15.42 & 33.53 \\
$-\Delta_{\mathrm{c}} u^{\circ} / \mathrm{J} \cdot \mathrm{g}^{-1}$ & 13046.10 & 18495.90 \\
\hline
\end{tabular}

$m$ (cpd) is the mass of compound burnt in each experiment; $m$ (fuse) is the mass of fuse (cotton) used in each experiment; $m$ (n-hexadec.) is the mass of $n$-hexadecane burnt in each experiment; $T_{\mathrm{i}}$ is the initial temperature rise; $T_{\mathrm{f}}$ is the final temperature rise; $\Delta T_{\mathrm{ad}}$ is the corrected temperature rise; $\varepsilon_{\mathrm{i}}$ is the energy equivalent of contents in the initial state; $\varepsilon_{\mathrm{f}}$ is the energy equivalent of contents in the final state; $\varepsilon_{\text {cal }}$ is the energy equivalent of the calorimeter; $\Delta m\left(\mathrm{H}_{2} \mathrm{O}\right)$ is the deviation of the mass of water added to the calorimeter from $2900.0 \mathrm{~g}$ or $5222.5 \mathrm{~g}$ depending of the calorimeter used; $\Delta U(\mathrm{IBP})$ is the energy change for the isothermal combustion reaction under actual bomb conditions and includes $\Delta U$ (ign); $\Delta U$ (fuse) is the energy of combustion of the fuse (cotton); $\Delta U$ (n-hexadec.) is the energy of combustion of $n$-hexadecane; $\Delta U\left(\mathrm{HNO}_{3}\right)$ is the energy correction for the nitric acid formation; $\Delta U$ (ign) is the electrical energy for ignition; $\Delta U_{\Sigma}$ is the standard state correction; $\Delta_{\mathrm{c}} u^{\circ}$ is the standard massic energy of combustion.

\section{Experimental results and discussion}

\subsection{Enthalpies of formation in the crystalline phase}

Results of a typical experiment for each compound are presented in table 2; $\Delta m\left(\mathrm{H}_{2} \mathrm{O}\right)$ is the deviation of the mass of water added to the calorimeter from $2900.0 \mathrm{~g}$ or $5222.5 \mathrm{~g}$, depending of the calorimeter used; $\Delta U_{\Sigma}$ is the energy correction to the standard state; $\Delta U(\mathrm{IBP})$ is the internal energy for the isothermal bomb process calculated according to equation (8). The remaining terms have been previously described [34,35].

$$
\begin{aligned}
\Delta U(\mathrm{IBP})= & \left\{-\varepsilon_{\mathrm{cal}}+C_{p}\left(\mathrm{H}_{2} \mathrm{O}, \mathrm{l}\right) \Delta m\left(\mathrm{H}_{2} \mathrm{O}\right)\right\} \Delta T_{\mathrm{ad}}+\left(T_{\mathrm{i}}\right. \\
& -298.15 \mathrm{~K}) \varepsilon_{\mathrm{i}}+\left(298.15-T_{\mathrm{i}}-\Delta T_{\mathrm{ad}}\right) \varepsilon_{\mathrm{f}}+\Delta U(\mathrm{ign}) .
\end{aligned}
$$

The standard massic energies of combustion, $\Delta_{c} u^{\circ}$, for hydantoin and 2-thiohydantoin, refer to the combustion reactions (9) and (10), respectively.

$$
\begin{aligned}
& \mathrm{C}_{3} \mathrm{H}_{4} \mathrm{~N}_{2} \mathrm{O}_{2}(\mathrm{cr})+3 \mathrm{O}_{2}(\mathrm{~g}) \rightarrow 3 \mathrm{CO}_{2}(\mathrm{~g})+2 \mathrm{H}_{2} \mathrm{O}(\mathrm{l})+\mathrm{N}_{2}(\mathrm{~g}), \\
& \mathrm{C}_{3} \mathrm{H}_{4} \mathrm{~N}_{2} \mathrm{OS}(\mathrm{cr})+5 \mathrm{O}_{2}(\mathrm{~g})+114 \mathrm{H}_{2} \mathrm{O}(\mathrm{l}) \\
& \quad \rightarrow 3 \mathrm{CO}_{2}(\mathrm{~g})+\mathrm{N}_{2}(\mathrm{~g})+\mathrm{H}_{2} \mathrm{SO}_{4} \cdot 115 \mathrm{H}_{2} \mathrm{O} .
\end{aligned}
$$

\begin{tabular}{|c|c|}
\hline Hydantoin & 2-Thiohydantoin \\
\hline \multicolumn{2}{|c|}{$-\Delta_{\mathrm{c}} u^{\circ} / \mathrm{J} \cdot \mathrm{g}^{-1}$} \\
\hline 13066.51 & 18478.82 \\
\hline 13041.06 & 18498.91 \\
\hline 13046.10 & 18487.61 \\
\hline 13036.72 & 18470.35 \\
\hline 13061.42 & 18495.90 \\
\hline 13053.15 & 18491.20 \\
\hline \multicolumn{2}{|c|}{$-<\Delta_{\mathrm{c}} u^{\circ}>/ \mathrm{J} \cdot \mathrm{g}^{-1}$} \\
\hline $13050.83 \pm 4.76$ & $18487.13 \pm 4.41$ \\
\hline
\end{tabular}

TABLE 3

Individual values of the standard $\left(p^{\circ}=0.1 \mathrm{MPa}\right)$ massic energy of combustion, of the compounds, at $T=298.15 \mathrm{~K}$. 
TABLE 4

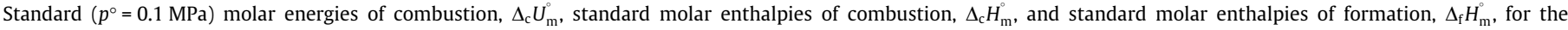
compounds studied, at $T=298.15 \mathrm{~K}$.

\begin{tabular}{|c|c|c|c|}
\hline Compound & $\Delta_{\mathrm{c}} U_{\mathrm{m}}^{\circ}(\mathrm{cr}) /\left(\mathrm{kJ} \cdot \mathrm{mol}^{-1}\right)$ & $\Delta_{\mathrm{c}} H_{\mathrm{m}}^{\circ}(\mathrm{cr}) /\left(\mathrm{kJ} \cdot \mathrm{mol}^{-1}\right)$ & $\Delta_{\mathrm{f}} H_{\mathrm{m}}^{\circ}(\mathrm{cr}) /\left(\mathrm{kJ} \cdot \mathrm{mol}^{-1}\right.$ \\
\hline Hydantoin & $1306.1 \pm 1.0$ & $1303.6 \pm 1.0$ & $448.6 \pm 1.1$ \\
\hline 2-Thiohydantoin & $2147.1 \pm 1.1$ & $2149.6 \pm 1.1$ & $204.6 \pm 1.3$ \\
\hline
\end{tabular}

TABLE 5

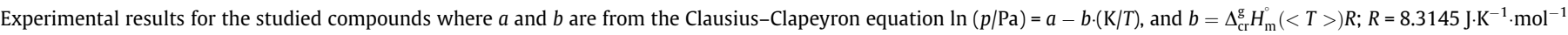

\begin{tabular}{|c|c|c|c|c|c|c|}
\hline Effusion orifices & $a$ & $b$ & $<T>/ K$ & $p(<T>) / \mathrm{Pa}$ & $\Delta_{\mathrm{cr}}^{\mathrm{g}} H_{\mathrm{m}}^{\circ}(<T>) /\left(\mathrm{kJ} \cdot \mathrm{mol}^{-1}\right)$ & $\Delta_{\mathrm{cr}}^{\mathrm{g}} S_{\mathrm{m}}\{<T>, p(<T>)\} /\left(\mathrm{J} \cdot \mathrm{K}^{-1} \cdot \mathrm{mol}^{-1}\right)$ \\
\hline \multicolumn{7}{|c|}{ Hydantoin } \\
\hline Series A & $34.76 \pm 0.25$ & $13799 \pm 97$ & & 0.497 & $114.7 \pm 0.8$ & $295 \pm 2$ \\
\hline Series B & $34.65 \pm 0.19$ & $13759 \pm 74$ & & 0.493 & $114.4 \pm 0.6$ & $294 \pm 2$ \\
\hline Mean & $34.71 \pm 0.31$ & $13779 \pm 122$ & 389.15 & 0.498 & $114.6 \pm 1.0$ & $294 \pm 3$ \\
\hline \multicolumn{7}{|c|}{ 2-Thiohydantoin } \\
\hline Series A & $34.64 \pm 0.10$ & $14139 \pm 41$ & & 0.457 & $117.6 \pm 0.3$ & $295 \pm 1$ \\
\hline Series B & $34.40 \pm 0.12$ & $14046 \pm 49$ & & 0.454 & $116.8 \pm 0.4$ & $293 \pm 1$ \\
\hline Mean & $34.52 \pm 0.16$ & $14093 \pm 64$ & 399.14 & 0.455 & $117.2 \pm 0.5$ & $294 \pm 1$ \\
\hline
\end{tabular}

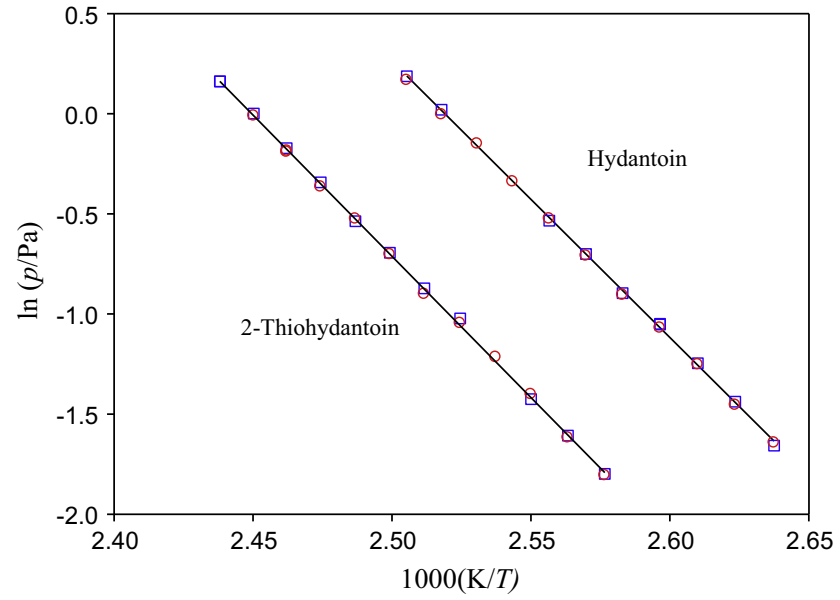

FIGURE 2. Plots of $\ln p$ against $1 / T$ for hydantoin and 2-thiohydantoin: $\square$, small effusion orifices; $\bigcirc$, medium effusion orifices.

Detailed results of each combustion experiment, for hydantoin and 2-thiohydantoin, are presented in tables S2 and S3, respectively, of the Supplementary information.

The results of all combustion experiments, with the mean values, $\left\langle\Delta_{\mathrm{c}} u^{\circ}\right\rangle$, and their standard deviation, are given in table 3 . The derived standard molar energies, $\Delta_{\mathrm{c}} U_{\mathrm{m}}^{\circ}(\mathrm{cr})$, and enthalpies of combustion, $\Delta_{\mathrm{c}} U_{\mathrm{m}}^{\circ}(\mathrm{cr})$, and the standard molar enthalpies of formation, in the crystalline phase, $\Delta_{\mathrm{f}} H_{\mathrm{m}}^{\circ}(\mathrm{cr})$ for each compound, at $T=298.15 \mathrm{~K}$, are given in table 4 . The uncertainties associated to the standard molar energy and enthalpy of combustion are twice the overall standard deviation of the mean and include the uncertainties in calibration with benzoic acid and in the energy of combustion of $n$-hexadecane, used as combustion auxiliary [36,37]. To derive $\Delta_{\mathrm{f}} H_{\mathrm{m}}^{\circ}(\mathrm{cr})$ from $\Delta_{\mathrm{c}} H_{\mathrm{m}}^{\circ}(\mathrm{cr})$, literature values of standard molar enthalpies of formation, at $T=298.15 \mathrm{~K}$, were used for $\mathrm{H}_{2} \mathrm{O}(\mathrm{l})$, $-(285.830 \pm 0.042) \mathrm{kJ} \cdot \mathrm{mol}^{-1}[38], \mathrm{CO}_{2}(\mathrm{~g}),-(393.51 \pm 0.13) \mathrm{kJ} \cdot \mathrm{mol}^{-1}$ [38] and $\mathrm{H}_{2} \mathrm{SO}_{4}$ in $115 \mathrm{H}_{2} \mathrm{O}(\mathrm{l}),-(887.81 \pm 0.42) \mathrm{kJ} \cdot \mathrm{mol}^{-1}$ [21].

\subsection{Enthalpies of sublimation}

The experimental results obtained from each effusion cell for the two compounds studied are presented in tables S4 and S5 of the Supporting information. For both compounds only six effusion cells (series A and series B) were used because the available amount of sample was not enough for using the nine effusion cells. The results do not show any significant influence of the size of the orifice in the measured vapour pressures. Table 5 presents for the series of effusion orifices the detailed parameters of the ClausiusClapeyron equation, $\ln (p / \mathrm{Pa})=a-b(\mathrm{~K} / T)$, where $a$ is a constant and $b=\Delta_{\mathrm{cr}}^{\mathrm{g}} H_{\mathrm{m}}^{\circ}(<T>) / R$, the standard molar enthalpies of sublimation at the mean temperature of the experiments and the entropies of sublimation at the equilibrium pressure and at $T=\langle T\rangle$, $\Delta_{\mathrm{cr}}^{\mathrm{g}} S_{\mathrm{m}}\{<T>, p(<T>)\}$. The plots of $\ln p=f(1 / T)$ for each compound studied are presented in figure 2 .

The standard molar enthalpies of sublimation at $T=298.15 \mathrm{~K}$ were derived from the sublimation enthalpies calculated at the mean temperature of the experiments, by equation (11), where $\Delta_{\mathrm{cr}}^{\mathrm{g}} C_{p, \mathrm{~m}}^{\circ}$ is the difference between the molar heat capacity at constant pressure between the gaseous phase and the crystalline phase. The values of the molar heat capacity of the gaseous phase, $C_{p, \mathrm{~m}}^{\circ}(\mathrm{g})$, at $T=298.15 \mathrm{~K}$, for the two compounds studied were calculated using computational chemistry. The geometry optimization, as well as the vibrational frequencies were performed using the B3LYP/6-31G(d) level of theory [39]. The frequencies were scaled using the scale factor of 0.9614 .

$\Delta_{\mathrm{cr}}^{\mathrm{g}} H_{\mathrm{m}}^{\circ}(298.15 \mathrm{~K})=\Delta_{\mathrm{cr}}^{\mathrm{g}} H_{\mathrm{m}}^{\circ}(<T>)+\Delta_{\mathrm{cr}}^{\mathrm{g}} C_{p, \mathrm{~m}}^{\circ}(298.15 \mathrm{~K}-<T>)$.

The values of $\Delta_{\mathrm{cr}}^{\mathrm{g}} C_{p, \mathrm{~m}}^{\circ}(298.15 \mathrm{~K})$ were calculated from $C_{p, \mathrm{~m}}^{\circ}(\mathrm{g})$, using equation (12) developed by Monte et al. [40], which is a rearrangement of equation (13) proposed by Chickos et al. [41]. Table 6 summarizes the values of gas phase molar heat capacities, the difference between gas and crystalline phase molar heat capacities and the enthalpies of sublimation, at $T=298.15 \mathrm{~K}$, derived from the vapour pressure measurements.

TABLE 6

Gas phase molar heat capacities, $C_{p, \mathrm{~m}}^{\circ}(\mathrm{g})$, difference between gas and crystalline phase molar heat capacities, $\Delta_{\mathrm{cr}}^{\mathrm{g}} C_{p, \mathrm{~m}}^{\circ}$, and enthalpies of sublimation, $\Delta_{\mathrm{cr}}^{\mathrm{g}} H_{\mathrm{m}}^{\circ}$, at $T=298.15 \mathrm{~K}$

\begin{tabular}{|c|c|c|c|}
\hline & $C_{p, \mathrm{~m}}^{\circ}(\mathrm{g}) /\left(J \cdot \mathrm{K}^{-1} \cdot \mathrm{mol}^{-1}\right)$ & $\Delta_{\mathrm{cr}}^{\mathrm{g}} C_{p, \mathrm{~m}}^{\circ} /\left(J \cdot \mathrm{K}^{-1} \cdot \mathrm{mol}^{-1}\right)$ & $\Delta_{\mathrm{cr}}^{\mathrm{g}} H_{\mathrm{m}}^{\circ} /\left(\mathrm{kJ} \cdot \mathrm{mol}^{-1}\right)$ \\
\hline Hydantoin & 99.92 & -18.5 & $116.3 \pm 0.7$ \\
\hline 2-Thiohydantoin & 104.00 & -19.2 & $119.1 \pm 0.4$ \\
\hline
\end{tabular}


TABLE 7

Experimental results obtained by Calvet microcalorimetry.

\begin{tabular}{|c|c|c|c|c|}
\hline Compound & $T_{\exp } / \mathrm{K}$ & $\Delta_{\mathrm{cr}, 298.15 \mathrm{~K}}^{\mathrm{g}, T} H_{\mathrm{m}}^{\circ} /\left(\mathrm{kJ} \cdot \mathrm{mol}^{-1}\right)$ & $\Delta_{298.15 \mathrm{~K}}^{T} H_{\mathrm{m}}^{\circ} /\left(\mathrm{kJ} \cdot \mathrm{mol}^{-1}\right)$ & $\Delta_{\mathrm{cr}}^{\mathrm{g}} H_{\mathrm{m}}^{\circ}(298.15 \mathrm{~K}) /\left(\mathrm{kJ} \cdot \mathrm{mol}^{-1}\right)$ \\
\hline Hydantoin & 447 & $131.0 \pm 0.5$ & 17.7 & $113.3 \pm 3.1$ \\
\hline 2-Thiohydantoin & 463 & $135.3 \pm 0.5$ & 20.4 & $115.0 \pm 2.1$ \\
\hline
\end{tabular}

$\Delta_{\mathrm{cr}}^{\mathrm{g}} C_{p, \mathrm{~m}}^{\circ}(\theta) / \mathrm{J} \cdot \mathrm{K}^{-1} \cdot \mathrm{mol}^{-1}=-\left\{0.9+0.176\left(C_{p, \mathrm{~m}}^{\circ}(\mathrm{g}) / \mathrm{J} \cdot \mathrm{K}^{-1} \cdot \mathrm{mol}^{-1}\right)\right\}$,

$\Delta_{\mathrm{cr}}^{\mathrm{g}} C_{p, \mathrm{~m}}^{\circ}(\theta) / \mathrm{J} \cdot \mathrm{K}^{-1} \cdot \mathrm{mol}^{-1}=-\left\{0.75+0.15\left(C_{p, \mathrm{~m}}^{\circ}(\mathrm{cr}) / \mathrm{J} \cdot \mathrm{K}^{-1} \cdot \mathrm{mol}^{-1}\right)\right\}$.

Measurements of the standard molar enthalpy of sublimation for the hydantoin and 2-thiohydantoin, obtained by Calvet microcalorimetry, are given in table 7. The observed enthalpies of sublimation, at the experimental temperature $T, \Delta_{\mathrm{cr}, 298.15 \mathrm{~K}}^{\mathrm{g}, T}$, were corrected to $T=298.15 \mathrm{~K}, \Delta_{\mathrm{cr}}^{\mathrm{g}} H_{\mathrm{m}}^{\circ}(298.15 \mathrm{~K})$, using the corrective term $\Delta_{298.15 \mathrm{~K}}^{T} H_{\mathrm{m}}^{\circ}(\mathrm{g})$ calculated by equation (14):

$\Delta_{298.15 \mathrm{~K}}^{T} H_{\mathrm{m}}^{\circ}(\mathrm{g})=\int_{298.15 \mathrm{~K}}^{T} C_{p, \mathrm{~m}}^{\circ}(\mathrm{g}) \mathrm{d} T$.

The values of $C_{p, \mathrm{~m}}^{\circ}(\mathrm{g})$, derived from computational chemistry [39], between $T=250 \mathrm{~K}$ and $T=500 \mathrm{~K}$, are listed in table S6. The derived $C_{p, \mathrm{~m}}^{\circ}(\mathrm{g})$ values are well adjusted by second degree polynomials yielding equations (15) and (16), for hydantoin and 2thiohydantoin, respectively.

$$
\begin{aligned}
C_{p, \mathrm{~m}}^{\circ}(\mathrm{g}) /\left(\mathrm{J} \cdot \mathrm{K}^{-1} \cdot \mathrm{mol}^{-1}\right)= & 4.00+0.3797(\mathrm{~T} / \mathrm{K})-1.934 \\
& \times 10^{-4}(\mathrm{~T} / \mathrm{K})^{2}, \quad\left(R^{2}=0.99998\right), \\
C_{p, \mathrm{~m}}^{\circ}(\mathrm{g}) /\left(\mathrm{J} \cdot \mathrm{K}^{-1} \cdot \mathrm{mol}^{-1}\right)= & 7.33+0.3845(T / \mathrm{K})-2.012 \\
& \times 10^{-4}(\mathrm{~T} / \mathrm{K})^{2}, \quad\left(R^{2}=0.99998\right) .
\end{aligned}
$$

The uncertainties associated to the values of $\Delta_{\mathrm{cr}}^{\mathrm{g}} H_{\mathrm{m}}^{\circ}(298.15 \mathrm{~K})$ are twice the overall standard deviation of the mean and include the uncertainties in calibration.

The values for $\Delta_{\mathrm{cr}}^{\mathrm{g}} H_{\mathrm{m}}^{\circ}(T=298.15 \mathrm{~K})$ derived from the vapour pressure measurements and from the Calvet microcalorimetry for hydantoin agree inside the associated experimental uncertainties, while for 2-thiohydantoin the difference between these values is $(4.1 \pm 2.1) \mathrm{kJ} \cdot \mathrm{mol}^{-1}$. Considering the lower uncertainties assigned to the results derived from the Knudsen effusion technique, these results were selected for determining the values of standard molar enthalpy of formation, in the gaseous phase, registered in table 8.

\subsection{Gas-phase: molecular structures}

The obtained optimized geometries of both compounds at the G3MP2B3 level of theory are shown in figure 3. Within this approach the geometry optimization is carried out at the B3LYP/6$31 \mathrm{G}(\mathrm{d})$ level of theory. Bond distances and angles are included.

As it can be seen from the figure, the inclusion of the sulphur atom is slightly distorting the 5-member's ring and both compounds are planar.
Our results are in a very good agreement with the experimental observations of several hydantoin and 2-thiohydantoin derivatives [42-61].

\subsection{Gas-phase enthalpies of formation}

The gas-phase enthalpies of formation of the two studied compounds were estimated taking into account the computed enthalpies of reactions described by equations (2)-(7) and the experimental enthalpies of formation in the gaseous phase of the other atoms and molecules there involved. The values of $\Delta_{\mathrm{f}} H_{\mathrm{m}}^{\circ}(\mathrm{g})$ were for carbon, $716.7 \mathrm{~kJ} \cdot \mathrm{mol}^{-1}$ [62], nitrogen, $472.7 \mathrm{~kJ} \cdot \mathrm{mol}^{-1}$ [62], hydrogen, $218.0 \mathrm{~kJ} \cdot \mathrm{mol}^{-1}$ [62], oxygen, $249.2 \mathrm{~kJ} \cdot \mathrm{mol}^{-1}$ [62], sulphur, $277.2 \mathrm{~kJ} \cdot \mathrm{mol}^{-1}$ [62], cyclohexane, $-123.3 \mathrm{~kJ} \cdot \mathrm{mol}^{-1}$ [63], N,N'-trimethyleneurea, $-201.1 \mathrm{~kJ} \cdot \mathrm{mol}^{-1}$ [7], benzene, $82.6 \mathrm{~kJ} \cdot \mathrm{mol}^{-1}$ [63], 2-benzimidazolinone, $-63.9 \mathrm{~kJ} \cdot \mathrm{mol}^{-1}$ [9], ethanal, $-166.1 \mathrm{~kJ} \cdot \mathrm{mol}^{-1}$ [63], tetrahydrofuran, $-184.1 \mathrm{~kJ} \cdot \mathrm{mol}^{-1}$ [63], 1,3-oxazolidin-2-thione, $-74.4 \mathrm{~kJ} \cdot \mathrm{mol}^{-1}[10]$, tetrahydrothiophene, $-33.5 \mathrm{~kJ} \cdot \mathrm{mol}^{-1}$ [63], 1,3-thiazolidin-2-thione, $97.1 \mathrm{~kJ} \cdot \mathrm{mol}^{-1}$ [10] and 2-pyrrolidinone, $-197.4 \mathrm{~kJ} \cdot \mathrm{mol}^{-1}$ [64].

Table 9 shows the calculated enthalpies of formation along with the experimental values. As it can be seen from the table, the agreement between the experimental and G3MP2B3 calculated values, is acceptable. The maximum deviations from the experimental results come from reactions described through equations (3) and (4). These deviations are of the same order of magnitude defined by the uncertainty associated to the experimental and calculated values [28]. The computed G3MP2B3 enthalpies for the studied compounds, auxiliary molecules, and atoms used in the atomization and working reactions are listed in table S7 in the Supporting information.

Comparing the values of the enthalpies of formation, in the gaseous phase, for the two compounds with the corresponding value for the imidazolidin-2-one, $-(176.7 \pm 2.2) \mathrm{kJ} \cdot \mathrm{mol}^{-1}$ [7], we can see that hydantoin is enthalpically the most stable, suggesting a reduction in the $\mathrm{C}=\mathrm{S}$ double bond character, i.e., a decrease of the mesomeric effect in 2-thiohydantoin, due to the lower conjugating properties of the sulfur $3 p$ orbitals relative to the oxygen 2 p orbitals. Furthermore, the vapour pressure measurements allow us to conclude that hydantoin is more volatile, being its crystalline state less stable than that of 2-thiohydantoin.

\subsection{Other gas-phase thermodynamic properties}

Other thermodynamic properties for the two titled compounds were also studied at the G3MP2B3 level of theory. The calculated values of adiabatic gas-phase basicity ( $\triangle G$ basicity), proton $(P A)$ and electron affinities (EA) and ionization enthalpies (IE) are regis-

\begin{tabular}{|c|c|c|c|}
\hline Compound & $\left.\Delta_{\mathrm{f}} H_{\mathrm{m}}^{\circ}(\mathrm{cr}) /\left(\mathrm{kJ} \cdot \mathrm{mol}^{-1}\right)\right)$ & $\left.\Delta_{\mathrm{cr}}^{g} H_{\mathrm{m}}^{\circ} /\left(\mathrm{kJ} \cdot \mathrm{mol}^{-1}\right)\right)$ & $\left.\Delta_{\mathrm{f}} H_{\mathrm{m}}^{\circ}(\mathrm{g}) /\left(\mathrm{kJ} \cdot \mathrm{mol}^{-1}\right)\right)$ \\
\hline Hydantoin & $-448.6 \pm 1.3$ & $116.3 \pm 0.7$ & $-332.3 \pm 1.3$ \\
\hline 2-Thiohydantoin & $-204.6 \pm 1.3$ & $119.1 \pm 0.4$ & $-85.5 \pm 1.4$ \\
\hline
\end{tabular}
tered in table 10.

TABLE 8

Derived standard $\left(p^{\circ}=0.1 \mathrm{MPa}\right)$ molar enthalpies of formation, at $T=298.15 \mathrm{~K}$. 


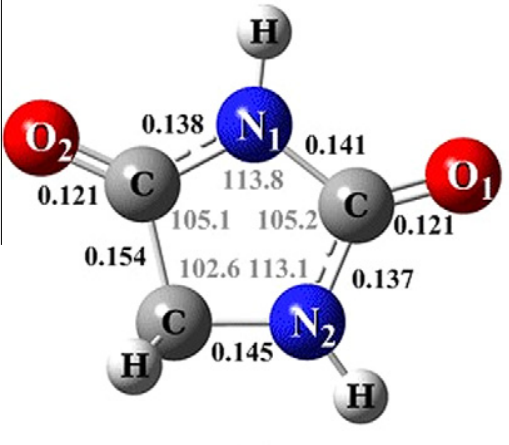

Hydantoin

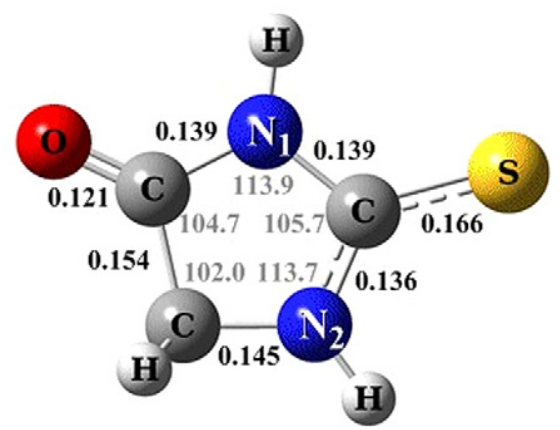

2-Thiohydantoin

FIGURE 3. Optimized geometries at the B3LYP/6-31G(d) level of theory. Bond distances are in nm and angles in degrees.

TABLE 9

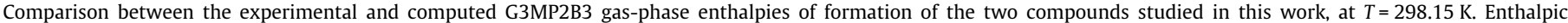
differences between the experimental and computed values are given in parentheses.

\begin{tabular}{|c|c|c|c|c|}
\hline \multicolumn{5}{|l|}{$\Delta_{\mathrm{f}} H_{\mathrm{m}}^{\circ} / \mathrm{kJ} \cdot \mathrm{mol}^{-1}$} \\
\hline \multirow[t]{2}{*}{ Compound } & \multicolumn{3}{|l|}{ G3MP2B3 } & \multirow[t]{2}{*}{ Experimental Value } \\
\hline & Atomization reaction (equation (2)) & Equation (3) & Equation (4) & \\
\hline Hydantoin & $\begin{array}{l}-336.3(-4.0) \\
\text { Atomization reaction (equation }(5))\end{array}$ & $\begin{array}{l}-337.7(-5.8) \\
\text { Equation }(6)\end{array}$ & $\begin{array}{l}-341.7(-9.4) \\
\text { Equation }(7)\end{array}$ & $-332.3 \pm 1.3$ \\
\hline 2-Thiohydantoin & $-94.0(-8.5)$ & $-82.4(+3.1)$ & $-86.3(-0.8)$ & $-85.5 \pm 1.4$ \\
\hline
\end{tabular}

TABLE 10

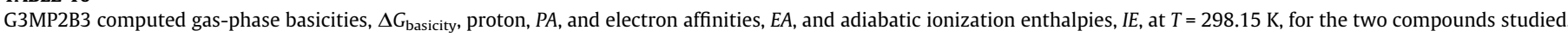
When available, experimental values are given in brackets.

\begin{tabular}{|c|c|c|c|c|}
\hline Compound & $\Delta G_{\text {basicity }} / \mathrm{kJ} \cdot \mathrm{mol}^{-1}$ & $\mathrm{PA} / \mathrm{kJ} \cdot \mathrm{mol}^{-1}$ & $E A / \mathrm{kJ} \cdot \mathrm{mol}^{-1}$ & $I E / \mathrm{kJ} \cdot \mathrm{mol}^{-1}$ \\
\hline Hydantoin & $\begin{array}{l}737.2\left(\mathrm{~N}_{1}\right) \\
777.3\left(\mathrm{~N}_{2}\right) \\
821.5\left(\mathrm{O}_{1}\right) \\
803.1\left(\mathrm{O}_{2}\right)\end{array}$ & $\begin{array}{l}734.8\left(\mathrm{~N}_{1}\right) \\
776.6\left(\mathrm{~N}_{2}\right) \\
821.7\left(\mathrm{O}_{1}\right) \\
803.5\left(\mathrm{O}_{2}\right)\end{array}$ & -61.6 & $976.8[984.1 \pm 4.8]^{a}$ \\
\hline 2-Thiohydantoin & $\begin{array}{l}738.5\left(\mathrm{~N}_{1}\right) \\
781.2\left(\mathrm{~N}_{2}\right) \\
852.3(\mathrm{~S}) \\
802.8(\mathrm{O})\end{array}$ & $\begin{array}{l}735.5\left(\mathrm{~N}_{1}\right) \\
779.8\left(\mathrm{~N}_{2}\right) \\
850.5(\mathrm{~S}) \\
803.0(\mathrm{O})\end{array}$ & -2.0 & 841.3 \\
\hline
\end{tabular}

${ }^{a}$ Reference [65].

As it can be seen from the table, the calculated gas-phase basicities of both compounds are similar for all their basic centres except for the carbonyl or thiocarbonyl group, the latest being the most basic ones. This fact is not surprising due to the stability of the corresponding cation. The positive charge is stabilized by resonance for the two nitrogen atoms, while for the other carbonyl groups the charge is stabilized only by one nitrogen atom. The proton affinity follows the same pattern.

Concerning the electron affinity, the addition of an electron to hydantoin or 2-thiohydantoin is not stabilizing any of these compounds as it is indicated by their negative values. This is due to the fact that an anti-bonding orbital is occupied in both and destabilizes the whole molecule. Finally, regarding the ionization enthalpies, it is possible to conclude that 2-thiohydantoin is the species which looses the electron easier.

No experimental or computational data have been found in the literature for comparison with our results on none of these properties excluding ionization enthalpies. In this case the available experimental data for hydantoin is in a very good agreement with our calculations.

\section{Acknowledgments}

Thanks are due to Fundação para a Ciência e Tecnologia (FCT), Lisbon, Portugal and to FEDER for financial support to Centro de
Investigação em Química, University of Porto. A.L.R.S. thanks FCT (Portugal) and FEDER for the award of a Ph.D. Grant (SFRH/BD/ 69606/2010).

\section{Appendix A. Supplementary data}

The analytical and spectral data, and spectral traces of the two compounds, as well as the dimensions of the effusion orifices (diameter and Clausing factors) of the Knudsen apparatus, the data and the details of all the combustion calorimetry experiments for the hydantoin and 2-thiohydantoin, the values of standard molar heat capacities in the gaseous phase for the two compounds, details of the fully optimized structures and the calculated energies of all compounds at the G3MP2B3 level of theory are available free of charge via Internet. Supplementary data associated with this article can be found, in the online version, at http://dx.doi.org/ 10.1016/j.jct.2012.10.010.

\section{References}

[1] T.R. Rodgers, M.P. Lamontagne, A. Markovac, A.B. Ash, J. Med. Chem. 20 (1977) 591-594.

[2] T. Anger, D.J. Madge, M. Mulla, D. Riddall, J. Med. Chem. 44 (2001) 115-137.

[3] S. Suzen, E. Buyukbingol, Farmaco 55 (2000) 246-248.

[4] E. Kleinpeter, Struct. Chem. 8 (1997) 161-173. 
[5] J.Z. Dávalos, M.D.M.C. Ribeiro da Silva, M.A.V. Ribeiro da Silva, V.L.S. Freitas, P. Jiménez, M.V. Roux, P. Cabildo, R.M. Claramunt, J. Elguero, J. Phys. Chem. A 114 (2010) 9237-9245.

[6] M.V. Roux, M. Temprado, P. Jimenez, C. Foces-Foces, R. Notario, A.R. Parameswar, A.V. Demchenko, J.S. Chickos, C.A. Deakyne, A.K. Ludden, J.F. Liebman, J. Phys. Chem. A 113 (2009) 10772-10778.

[7] M.D.M.C. Ribeiro da Silva, M.A.V. Ribeiro da Silva, V.L.S. Freitas, M.V. Roux, P. Jiménez, M. Temprado, J.Z. Dávalos, P. Cabildo, R.M. Claramunt, J. Elguero, J. Chem. Thermodyn. 40 (2008) 386-393.

[8] M.D.M.C. Ribeiro da Silva, M.A.V. Ribeiro da Silva, V.L.S. Freitas, M.V. Roux, P. Jiménez, J.Z. Dávalos, P. Cabildo, R.M. Claramunt, J. Elguero, J. Chem. Thermodyn. 40 (2008) 1378-1385.

[9] V.M.F. Morais, M.S. Miranda, M.A.R. Matos, J.F. Liebman, Mol. Phys. 104 (2006) 325-334.

10] M.V. Roux, M. Temprado, P. Jimenez, C. Foces-Foces, R. Notario, A.R. Parameswar, A.V. Demchenko, J.S. Chickos, C.A. Deakyne, J.F. LiebmanJ, Phys. Chem. A 114 (2010) 6336-6341.

[11] A.L.R. Silva, A. Cimas, M.D.M.C. Ribeiro da Silva, J. Chem. Thermodyn. 57 (2013) 212-219.

[12] N.I. El-Sayed, Asian J. Chem. 5 (1993) 199-207.

[13] R. Sabbah, A. Xu-wu, J.S. Chickos, M.L.P. Leitão, M.V. Roux, L.A. Torres Thermochim. Acta 331 (1999) 93-204.

[14] C.L. Yaws, D.H. Chen, in: C.L. Yaws (Ed.), Thermophysical Properties of Chemicals and Hydrocarbons; William Andrew Inc., New York, 2008. (Chapter 5).

[15] M.E. Wieser, T.B. Coplen, Pure Appl. Chem. 83 (2011) 359-396.

[16] M.D.M.C. Ribeiro da Silva, L.M.N.B.F. Santos, A.L.R. Silva, O. Fernandes, W.E. Acree Jr., J. Chem. Thermodyn. 35 (2003) 1093-1100.

[17] M.A.V. Ribeiro da Silva, M.L.C.C.H. Ferrão, F. Jiye, J. Chem. Thermodyn. 26 (1994) 839-846.

[18] J. Coops, R.S. Jessup, K. vanNes, in: F.D. Rossini (Ed.), Experimental Thermochemistry, vol. 1, Interscience, New York, 1956 (Chapter 3).

19] E.N. Washburn, J. Res. Natl. Bur. Stand. (U.S.) 10 (1933) 525-558.

[20] A.I. Vogel, Quantitative Inorganic Analysis, Longman, London, 1978.

[21] D.A. Wagman, W.H. Evans, V.B. Parker, R.H. Schumm, I. Halow, S.M. Bailey, K.L. Churney, R.L. Nuttall, The NBS Tables of Chemical Thermodynamics Properties, J. Phys. Chem. Ref. Data II (Suppl. 2) 1982

[22] W.N. Hubbard, D.W. Scott, G. Waddington, in: F.D. Rossini (Ed.), Experimental Thermochemistry, vol. 1, Interscience, New York, 1956 (Chapter 5).

[23] W.D. Good, D.W. Scott, in: H.A. Skinner, (Ed.), Experimental Thermochemistry, vol. 2, Interscience, New York, 1962 (Chapter 2).

[24] M.A.V. Ribeiro da Silva, M.J.S. Monte, L.M.N.B.F. Santos, J. Chem. Thermodyn. 38 (2006) 778-787.

[25] F.A. Adedeji, D.L.S. Brown, J.A. Connor, W.L. Leung, I.M. Paz-Andrade, H.A Skinner, J. Organomet. Chem. 97 (1975) 221-228.

[26] L.M.N.B.F. Santos, B. Schröder, O.O.P. Fernandes, M.A.V. Ribeiro da Silva Thermochim. Acta 415 (2004) 15-20.

[27] M.J. Frisch, G.W. Trucks, H.B. Schlegel, G.E. Scuseria, M.A. Robb, J.R. Cheeseman, V.G. Zakrzewski, J.A.J. Montgomery, R.E. Stratmann, J.C. Burant, S. Dapprich, J.M. Millam, A.D. Daniels, K.N. Kudin, M.C. Strain, O. Farkas, J. Tomasi, V. Barone, M. Cossi, R. Cammi, B. Mennucci, C. Pomelli, C. Adamo, S. Clifford, J. Ochterski, G.A. Petersson, P.Y. Ayala, Q. Cui, K. Morokuma, D.K. Malick, A.D. Rabuck, K. Raghavachari, J.B. Foresman, J. Cioslowski, J.V. Ortiz, B.B. Stefanov, G. Liu, A. Liashenko, P. Piskorz, I. Komaromi, R. Gomperts, R.L. Martin, D.J. Fox, T. Keith, M.A. Al-Laham, C.Y. Peng, A. Nanayakkara, C. Gonzalez, M. Challacombe, P.M.W. Gill, B. Johnson, W. Chen, M.W. Wong, J.L. Andres, M Head-Gordon, E.S. Replogle, J.A. Pople, Gaussian03, Revision C.01; Gaussian, Inc: Wallingford CT, 2004

[28] A.G. Baboul, L.A. Curtiss, P.C. Redfern, K. Raghavachari, J. Chem. Phys. 110 (1999) 7650-7657.

[29] L.A. Curtiss, P.C. Redfern, K. Raghavachari, V. Rassolov, J.A. Pople, J. Chem. Phys 110 (1999) 4703-4709.

[30] A.D. Becke, J. Chem. Phys. 98 (1993) 5648-5652.
[31] P.J. Stephens, F.J. Devlin, C.F. Chabalowski, M.J. Frisch, J. Phys. Chem. 98 (1994) $11623-11627$.

[32] C. Lee, W. Yang, R.G. Parr, Phys. Rev. B 37 (1988) 785-789.

[33] L.A. Curtiss, K. Raghavachari, P.C. Redfern, V. Rassolov, J.A. Pople, J. Chem. Phys, 109 (1998) 7764-7776.

[34] W.N. Hubbard, D.W. Scott, G. Waddington, in: F.D. Rossini (Ed.), Experimental Thermochemistry, vol. 1, Interscience, New York, 1956 (Chapter 5).

[35] L.G. Bjellerup, in: H.A. Skinner (Ed.), Experimental Thermochemistry, vol. 2 , Interscience, New York, 1962 (Chapter 3).

[36] F.D. Rossini, in: F.D. Rossini (Ed.), Experimental Thermochemistry, vol. 1, Interscience, New York, 1956 (Chapter 14).

[37] G. Olofson, in: S. Sunner, M. Månsson (Eds.), Combustion Calorimetry, vol. 1, Pergamon Press, Oxford, 1979 (Chapter 6).

[38] J.D. Cox, D.D. Wagman, V.A. Medvedev, CODATA Key Values for Thermodynamics, Hemisphere, New York, 1989.

[39] K.K. Irikura, THERMO.PL, National Institute of Standards and Technology, <http://www.cstl.nist.gov/div838/group_06/irikura/prog/thermo.html>, 2002.

[40] M.J.S Monte, A.R.R.P. Almeida, M.A.R. Matos, J. Chem. Eng. Data 55 (2010) 419-

[41] J.S. Chickos, S. Hosseini, D.G. Hesse, J.F. Liebman, Struct. Chem. 4 (1993) 271278

[42] H.R. Henze, G.R. Allen, J. Am. Chem. Soc. 77 (1955) 461-464.

[43] L.A. Walker, K. Folting, L.L. Merritt Jnr, Acta Cryst. B25 (1969) 88-93.

[44] P. Smithverdier, F. Florencio, S. Garciablanco, Acta Cryst. B33 (1977) 33813385.

[45] F. Florencio, P. Smith-Verdier, S. García-Blanco, Acta Cryst. B34 (1978) 13171321.

[46] F. Florencio, P. Smith-Verdier, S. García-Blanco, Acta Cryst. B34 (1978) 22202223.

[47] P. Smith-Verdier, F. Florencio, S. García-Blanco, Acta Cryst. B35 (1979) 216217.

[48] J. Vilches, F. Florencio, S. García-Blanco, Acta Cryst. B37 (1981) 361-364.

[49] J. Vilches, F. Florencio, P. Smith-Verdier, S. García-Blanco, Acta Cryst. B37 (1981) 2076-2079.

[50] R.E. Cassady, S.W. Hawkinson, Acta Cryst. B38 (1982) 2206-2209.

[51] N.N. Dhaneshwar, S.S. Tavale, T.N. Guru Row, Acta Cryst. C41 (1985) 13201322.

[52] M.J. Heeg, P. Subramanian, G. Dryhurst, Acta Cryst. C42 (1986) 747-750

[53] M.F. Mackay, B.M. Duggan, R.L. Laslett, J.F.K. Wilshire, Acta Cryst. C48 (1992) 334-336.

[54] Z. Galdecki, J. Karolakwojciechowska, J. Cryst. Spect. Res. 16 (1986) 467-474.

[55] G. Coquerel, M.N. Petit, F. Robert, Acta Cryst. C49 (1993) 824-825.

[56] K. Honda, M. Goto, I. Kojima, Anal. Sci. 11 (1995) 879-880.

[57] E. Benedetti, E.M. Pedone, N.H. Kawahata, M. Goodman, Biopolymers 36 (1995) 659-667.

[58] G.Y. Lee, Y.S. Lee, M. Koo, K.J. Lee, Bull. Korean Chem. Soc. 20 (1999) 13591362.

[59] M.M. Chowdhry, D.M.P. Mingos, A.J.P. White, D.J. Williams, J. Chem. Soc., Perkin Trans. 1 (2000) 3495-3504.

[60] ] B. Zorc, M. Cetina, D. Mrvos-Sermek, S. Raic-Malic, M. Mintas, J. Pept. Res. 66 (2005) 85-93.

[61] Ko-Ki Kunimoto, M. Ichitani, T. Ogawa, Soh-ichi Kitoh, A. Kuwae, A. Hanai, Spect. Lett. 42 (2009) 73-80.

[62] M.W. Jr Chase, J. Phys. Chem. Ref. Data, Monograph 9 (1998) 1-1951.

[63] J.P. Pedley, Thermochemical Data and Structures of Organic Compounds, Thermodynamics Research Centre, College Station, Texas, 1994.

[64] W.V. Steele, R.D. Chirico, A. Nguyen, I.A. Hossenlopp, N.K. Smith, AIChE Symp. Ser. 85 (1989) 140-162.

[65] T. Vondrak, C. Cauletti, Spectrochim. Acta A 44 (1988) 289-292.

JCT $12-544$ 